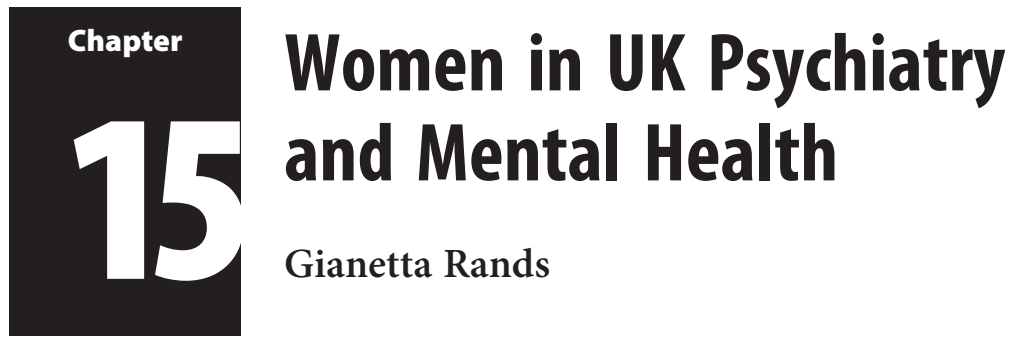

\title{
Introduction
}

Throughout this chapter, it is accepted that women's mental and emotional health are affected by their roles in society, their relationships with other people, their own health and welfare and their financial independence. Some relevant laws enacted between 1960 and 2010 are described. Some experiences of women as mental health professionals and as patients during this time period are considered.

\section{Women's Lives in 1960}

One source of insight into the lives of women at the end of the 1950s and during the 1960s is Jennifer Worth's book Call the Midwife (2002), ${ }^{1}$ later turned into a BBC series portraying people's lives in London's docklands. Many women stopped working when they married. Sex before marriage was frowned upon. Women often had ten or more children. Maternal death rates were high, usually due to postpartum haemorrhage or sepsis. Contraception was the rhythm method or condoms. Illegal terminations could be procured as 'back street abortions' that too often resulted in fatal sepsis or painful pelvic scarring and infertility. Large extended families lived in small tenements with outdoor toilets and no hot water. Domestic violence was brushed off by police and others as 'just a domestic'.

In 1960, most psychiatric treatment took place in large mental hospitals, the old lunatic asylums, that were among the first employers to provide equal pay to men and women, thanks to Henry Fawcett. ${ }^{2}$ These were also some of the first medical institutions to employ women doctors, some of whom progressed to careers as psychiatrists, such as Eleanora Fleury and Helen Boyle.

By the early 1960s, conditions in the asylums were miserable for patients and staff, as described by Bradley. ${ }^{3}$ Barbara Robb, a psychoanalyst working in north London, was horrified by conditions in her local asylum. Her book Sans Everything shook the establishment and the long process of closing asylums began (see also Chapters 1 and 7). ${ }^{4}$

\section{Mother's Little Helper}

'The problem that has no name' slowly emerged in the consciousness of Betty Friedan as she analysed replies to a questionnaire sent to her cohort of 1942 graduates from Smith College, a women-only university in Massachusetts, United States. Women in the late 1950s and early 1960s were not happy. When they consulted their doctors there was 'nothing wrong' with them. Their problem had no name. Friedan's analysis evolved into her book The Feminine Mystique described by the New York Times as 'one of the most influential non-fiction books of the twentieth century'. 


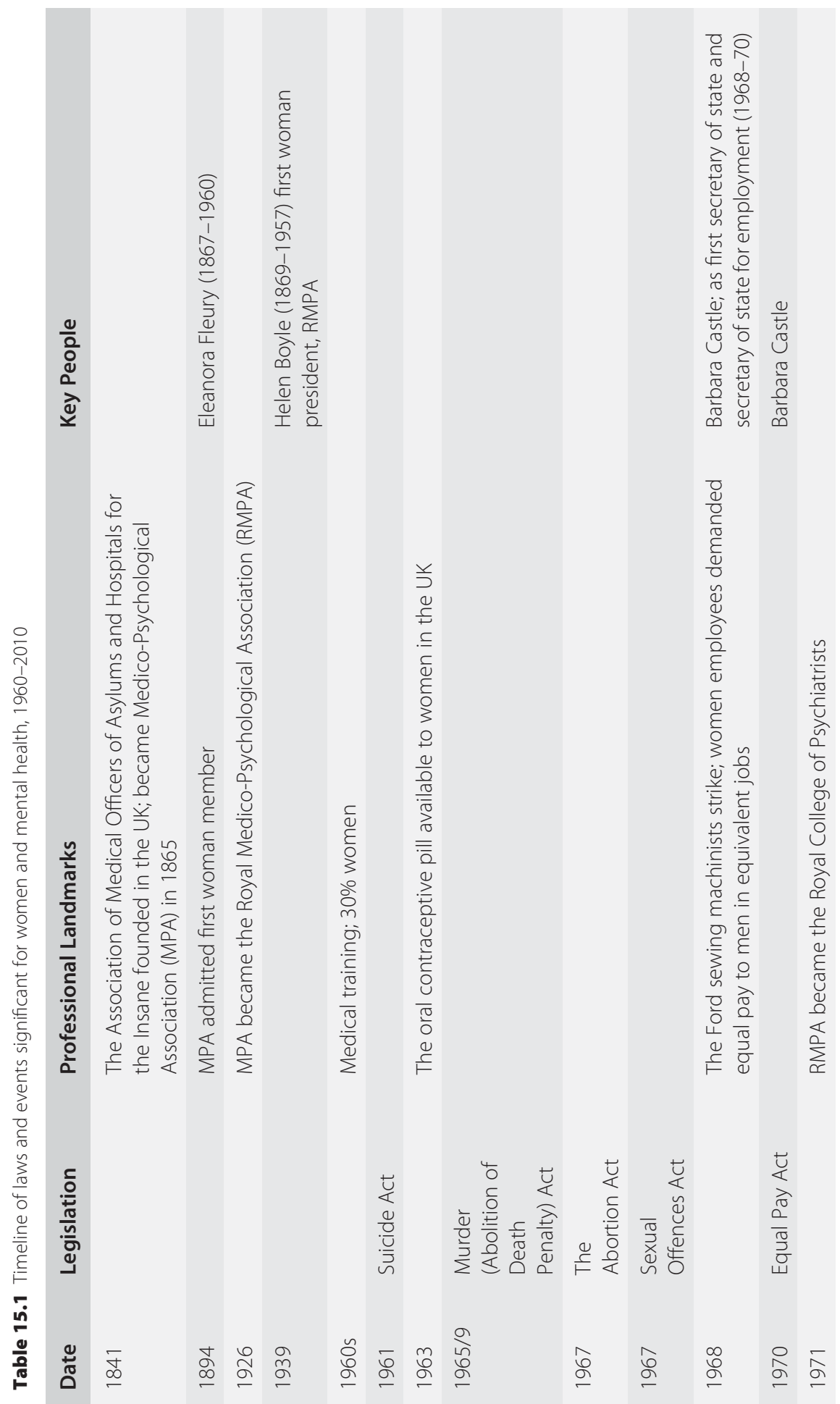




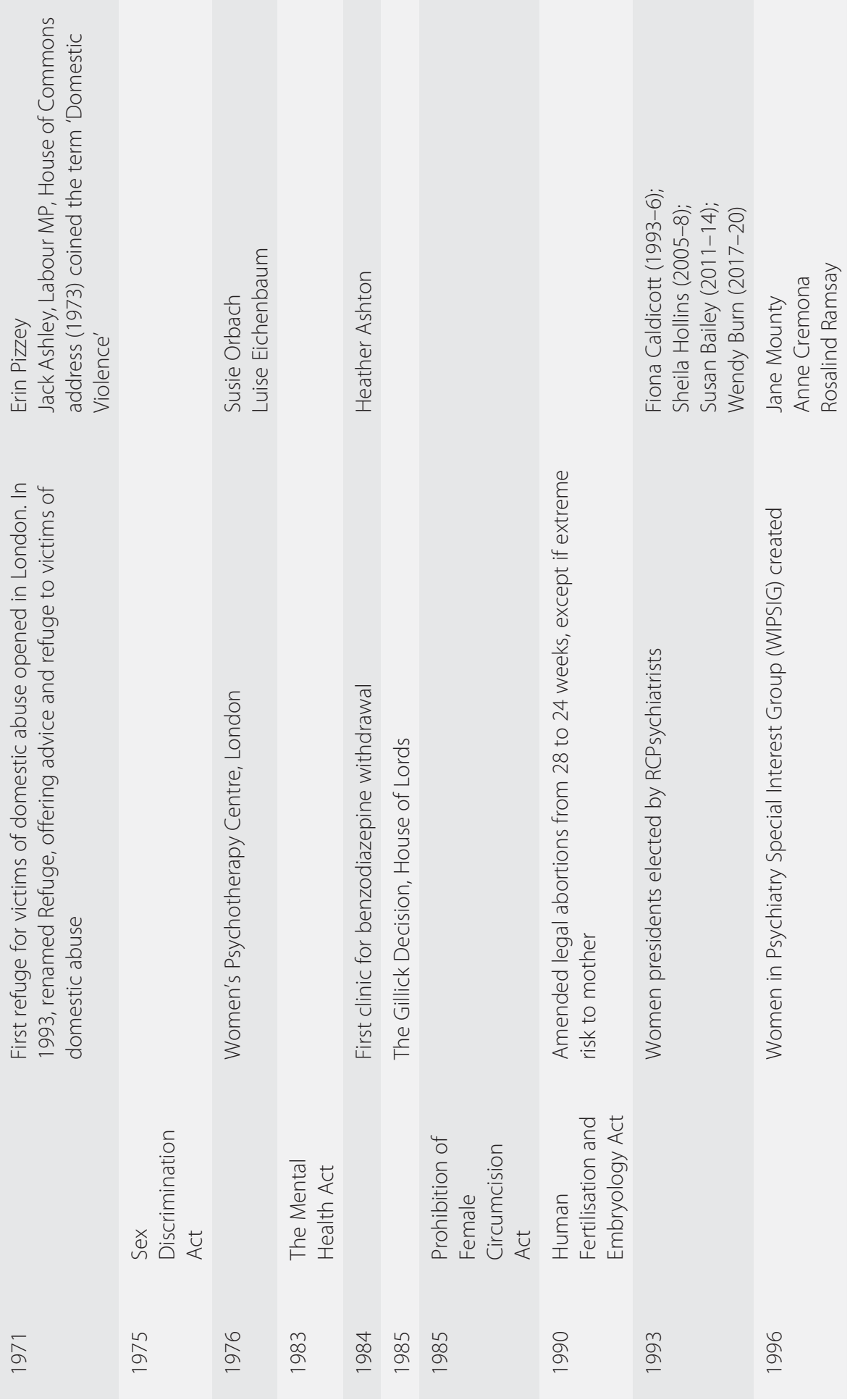




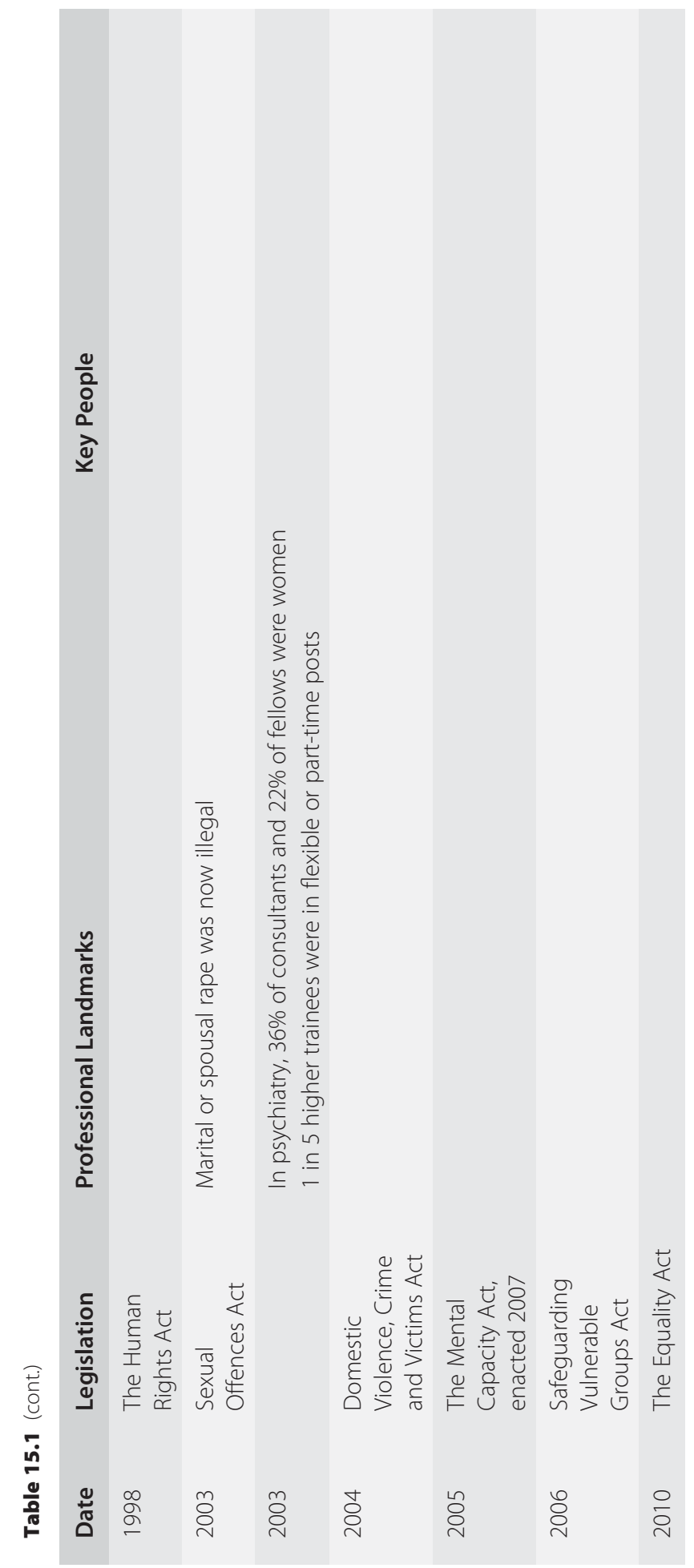


One of many republications of this book is a Penguin Modern Classic edition, 2010, with an introduction by Lionel Shriver. ${ }^{5}$ Shriver refers to the award-winning television series Mad Men, in particular the character Mrs Betty Draper as the embodiment of the feminine mystique. She has everything a woman could want - handsome high-earning husband, beautiful suburban house filled with modern domestic gadgets, two healthy children, time for self-pampering and money for pretty clothes. She had married young and rejoiced that she wasn't a frumpy 'career-girl'. Why was she unhappy?

Although Friedan's research has been criticised for focusing on a few hundred, middleclass, highly educated, white women in the United States, her findings showed insights into a massive, international problem. The Feminine Mystique has been credited with sparking the second wave of feminism in which equality was the main issue.

Other Smith College alumna are Nancy Reagan, Barbara Bush, Gloria Steinem and Sylvia Plath (Class of 1955). Plath, in her writings and her tragic short life, embodied something of the problem that has no name. As a talented poet and writer, the restrictions and drudgery of being a housewife overwhelmed her mental health. She was diagnosed as clinically depressed, received electroconvulsive therapy (ECT) and tragically killed herself in 1963.

Sylvia Plath died in London. A few miles away, Mick Jagger and Keith Richards were creating their legendary rock and roll genre. In 1966, they released this song:

\section{Mother's Little Helper \\ Kids are different today, I hear every mother say \\ Mother needs something today to calm her down \\ And though she's not really ill, there's a little yellow pill \\ She goes running for the shelter of a mother's little helper \\ And it helps her on her way, gets her through her busy day}

It goes on:

\section{And if you take more of those, you will get an overdose}

No more running for the shelter of a mother's little helper

They just helped you on your way, to your busy dying day

These lyrics were seen as a response to public criticism of the younger generation's use of recreational drugs at a time when married women were being prescribed increasing amounts of calming medications such as meprobamate and diazepam (Mother's Little Helper). Both these drugs are prescribed sedatives and are now known to be addictive. Meprobamate (Miltown or Equanil) can be lethal in overdose. Valium (diazepam), one of the first benzodiazepine group of drugs, was launched in 1963, and in 1978 more than 2 billion tablets were prescribed in the United States alone.

In 1984, in her practice in Newcastle, Heather Ashton noticed the difficulties people had in withdrawing from benzodiazepines and set up the first clinic to help with this. Her manual Benzodiazepines: How They Work and How to Withdraw has guided millions around the world in this difficult task. ${ }^{6}$

Sedation was an easy way to manage women presenting with 'the problem that had no name'. As in the case of Betty Draper, alcohol was another sedative increasingly resorted to by unhappy housewives.

As the 1960s progressed towards the 'Summer of Love' (1969), addiction to sedatives, alcohol and other recreational drugs all spiralled (see also Chapter 25). Another group of 
medications that had a massive effect on the mental and physical health of women was the pill: oral contraception for women.

\section{The Pill: Women Control Family Planning}

The oral contraceptive (OC) pill is a tablet taken every day, or twenty-one per twentyeight day cycle, by women wanting to avoid pregnancy. Interest in combining a progesterone-type drug with an oestrogen-type drug for this purpose started in the 1930s. It wasn't until synthetic versions of these hormones were available that they could be tested in women. In the UK, the first OCs were made available via Family Planning Clinics (FPCs) from 1963.

By 2010, thirty-three varieties of combined OC, five varieties of progesterone-only OC and other hormonal contraception such as subcutaneous implants, intrauterine devices and vaginal rings were available in the UK. The pill could be prescribed to girls under sixteen provided they were 'Gillick competent' in which case 'parental rights' do not exist. $^{7}$

The impact on women's lives and health was huge. Not only could they control their fertility but these drugs were used for other inconvenient and incapacitating conditions such as menorrhagia (heavy bleeding), dysmenorrhoea (painful periods), endometriosis, premenstrual tension and acne.

Women's health improved because they were not constantly having babies. The risks associated with pregnancy, such as death, septicaemia, anaemia, urinary tract infections, incontinence and deep-vein thrombosis, reduced as the number of pregnancies reduced. The age that women married increased, the number of children they had decreased and more women succeeded in higher education and professional careers. There were concerns that decoupling sex and pregnancy caused an increase in promiscuity and pressure on young women to have sex before they were fully consenting.

With effective contraception available, women with serious illnesses, be they mental, physical or genetic predispositions, could choose whether or not to have babies. For instance, a woman with bipolar affective disorder needing lithium to stay well could choose to avoid pregnancy as lithium is toxic to the foetus (teratogenic).

\section{Mental IIlnesses Associated with the Menstrual Cycle and Pregnancy}

The three main psychiatric diagnoses associated with the menstrual cycle and pregnancy are premenstrual dysphoric disorder, postnatal depression and postpartum psychosis.

Premenstrual tension refers to a collection of mood and somatic symptoms experienced by many women in the luteal phase of their cycles, that is, after ovulation and before menstruation. Some 3-8 per cent of women experience severe symptoms that constitute a diagnosis of premenstrual dysphoric disorder. These women have a higher risk of postnatal depression and mood disorders during their menopause.

Postnatal depression affects 10-15 per cent of new mothers within the first two months of giving birth and sometimes starts in the last few months of pregnancy. Postpartum psychosis affects about 1 in 1,000 women who give birth and usually 
comes on very quickly in the first few weeks after having a baby. It has a high risk of suicide and infanticide and needs urgent treatment, usually in hospital and preferably in a mother and baby unit.

These conditions are treatable once they are diagnosed. Research and collaborations between psychiatrists, obstetricians, gynaecologists, general practitioners and scientists led to criteria for diagnoses and improvements in services and training. By the end of the 2010s, these mental illnesses were taken seriously in the UK. ${ }^{8}$

\section{Laws Affecting Women in UK Psychiatry and Mental Health, 1960-2010}

In 1961, the Suicide Act was passed. Before this, anyone found trying to kill themselves could be prosecuted and imprisoned. This law applied to England and Wales. In Scotland, suicide was never an offence. In Northern Ireland, text from the Suicide Act was incorporated into their Criminal Justice Act 1966.

The Abortion Act, passed in October 1967 and effective from April 1968, made medical termination of pregnancy (abortion) legal up to twenty-eight weeks in England, Wales and Scotland. A pregnant woman could obtain termination of her pregnancy if two medical practitioners agreed that continuing with that pregnancy would risk her life, mental or physical health, or put any of her existing children at risk. Northern Ireland decriminalised abortion in October 2019, effective from 31 March 2020. To quote Bradley 'unwanted pregnancy, whether due to contraceptive failure, rape or incest was often a precursor of severe depression or suicide'.

The Sexual Offences Act 1967 legalised homosexuality between consenting men aged twenty-one years and over, reduced to eighteen years and over in 1994. Before then, women, knowingly or unknowingly, willingly or unwillingly, in sham marriages would have experienced collateral damage, suffering confusion, deceit, emotional distress and mental illnesses.

Barbara Castle, in her roles as first secretary of state and secretary of state for employment (1968-70) intervened in the Ford machinists strike of 1968 in which women employees demanded pay equal to their men colleagues in equivalent jobs. The awareness of widespread pay inequality precipitated the Equal Pay Act 1970 which gained royal assent in May 1970 but was, curiously, not commenced until 1975. It made discrimination between men and women, in their terms and conditions of employment, illegal. It applied to the whole of the UK except Northern Ireland. Castle, in her role as minister of transport (1965-8), also introduced breathalysers, seat belts and speed limits, all of which have benefited the lives of women.

The Sex Discrimination Act 1975 gained royal assent in November 1975. It specifically covered discrimination and harassment on the grounds of sex or marital status in employment, training and education. It was one of a clutch of equality and discrimination laws that were repealed and incorporated into the Equality Act in 2010.

The current version of the Equality Act 2010 lists protected characteristics as age, disability, gender reassignment, marriage and civil partnership, race, religion or belief, sex and sexual orientation. ${ }^{10}$ Discrimination, harassment and victimisation are prohibited in employment and private and public services. The Act applies in England, Wales and Scotland but has limited application in Northern Ireland. 
Other legislation passed in the UK during this time period and relevant to the mental health of women includes the Prohibition of Female Circumcision Act 1985 and the Domestic Violence, Crime and Victims Act 2004 which gave legal protection to victims of crime, particularly domestic violence. The first refuge for women victims of domestic violence opened in London in 1971. The Sexual Offences Act 2003 made marital, or spousal, rape illegal. Before that, a husband could force 'conjugal rights' on his wife claiming ongoing consent through their marriage contract. The 2003 Act reinforced the importance of consent and that, if someone is unable to consent or their consent is obtained by force or intimidation, the sex act is not consensual.

The Human Rights Act was passed in the UK in 1998. It legislated that public organisations, including government, police and local councils, must treat every person resident in the UK equally, with fairness, dignity and respect. It is based on articles of the European Convention on Human Rights (ECHR). Another important law incorporating ECHR articles as principles is the Mental Capacity Act 2005, commenced in 2007. This Act enshrines a person's right to make their own decisions based on informed consent and defines a process for making decisions when a person lacks mental capacity.

\section{The Feminist Movement}

Women's movements have a long history, at least 500 years, and international representation. Friedan describes progress made as 'two steps forward, one step back' ${ }^{11}$ Since then feminism has been documented as 'waves', which inevitably implies troughs.

Feminism as an ideology is based on equality of men and women in all aspects of society, education, employment, politics, economics and human rights. It is about equality of value, opportunity and reward. The principles of feminism have been incorporated into many areas, such as feminist philosophy, psychology and sociology, and into specific groups, such as black and intersectional feminism.

First-wave feminism covers women's rights movements' demand for, and gain of, suffrage. Many also demanded equality of educational opportunities. This aim continued into the second wave of feminism, in the 1960s and 1970s, that primarily focused on equality and nondiscrimination. As these ideals were enshrined in laws, there was the reasonable assumption that they would soon be achieved. It slowly became evident that this was not so, igniting the third wave of feminism in the early 1990s. This was more multiracial than previous waves, and the concept that social conditioning was the cause of gender inequalities and discriminations was key. The phrase 'a matrix of domination' incorporates the idea that gender inequality interacts with homophobia, classism, colonisation and capitalism across the globe, in a way that holds back progress in all those areas. ${ }^{12}$ The use of social media around 2010 sparked new interest in feminism which started ripples of the fourth wave.

Feminists of the 1970s reinstated the title 'Ms' as a formal way to address women without specifying their marital status. It had previously been used in the seventeenth and eighteenth centuries when, like 'Miss' and 'Mrs', it was a derivation of Mistress. Doctors in the 1920s rejected the title 'Doctress' and many women doctors use Dr or Professor not only because they indicate training and academic achievements but also because they are non-gendered titles. 


\section{Aspects of Mental Health Services, 1960-2010}

With mental health services in the 1960s under-resourced and neglected, the anti-psychiatry movement was an attractive alternative (see also Chapter 20). In the 1970s, there was a flurry of reports about sexual and violent crimes on psychiatry wards and inappropriate behaviour of professionals. The Kerr/Haslam Inquiry (2005) investigated two psychiatrists, William Kerr and Michael Haslam, working in York in the 1970s and 1980s, both of whom had been found guilty of indecent assaults against women psychiatric patients. ${ }^{13}$ The report found that numerous complaints had not been taken seriously; professionals raising concerns (whistle-blowing) were not heard; whistle-blowing was detrimental to careers; and there was a culture of loyalty to colleagues, tolerance of sexualised behaviours and a predominantly male hierarchy of doctors and female nurses that reinforced gender power dynamics.

Several good recommendations were made. All Mental Health Trusts were to display information leaflets about assessments and treatments. Complaints procedures needed to be clear, and Independent Mental Health Advocates (IMHAs) and Patient Advice and Liaison Services (PALS) were to be provided. The report's recommendations about protecting vulnerable adults were incorporated into the Safeguarding Vulnerable Groups Act 2006. ${ }^{14}$

In the 1980s, the psychiatric paradox was described. Women go to psychiatry services for help but instead get blamed for their own illnesses and those of others. Penfold and Walker write that

'Blame the victim' models lead to the scapegoating of mothers, blaming the rape victim and battered wife, dismissing the prostitute as primitive or deviant, accusing the alcoholic's wife of causing her husband's downfall, pointing the finger at the little girl who is assumed to have seduced her innocent father, and attributing women's addiction to tranquillisers to neuroticism and inadequacy. ${ }^{15}$

They describe protection of perpetrators with reference to psychiatry's function as a social regulator.

Perusal of standard psychiatry textbooks from the 1980s provides evidence for some of these allegations. Their indexes contain few references to women, abuse or perinatal illnesses. A short paragraph about the mental effects of the menopause concludes 'psychiatric symptoms at this time of life could equally well reflect changes in the woman's role as her children leave home, her relationship with her husband alters, and her own parents become ill or die'. The recommendations of the Kerr/Haslam report were needed and eventually implemented throughout the UK.

The Women's Therapy Centre, London, opened in 1976 to offer individual and group psychotherapy to women who, for many reasons, were not able to access other mental health services. It was a social enterprise started by psychotherapists Susie Orbach and Luise Eichenbaum based on their principles of social feminism and their skills in psychotherapy and psychoanalysis. Some of its successes have been to increase the understanding of what it means to grow up as a girl in patriarchal societies, to expand their developmental theory and feminist relational practice and to write books and lectures that are used internationally.

Developments in Mental Health Services since 1960 that have specifically benefited women include Perinatal Psychiatry, Child and Adolescent Mental Health Services, Intellectual Disability and Old Age Psychiatry, the latter because women live longer than 
men. There have been extensive debates about women-only wards that usually conclude that what matters is good, well resourced, multi-professional teams providing assessment and treatment in a co-operative, collegiate way, with sufficient resources to do their jobs well. With these in place, the demands for single-sex wards diminish.

Private psychoanalysis and psychotherapy thrived in many areas of the UK from 1960 to 2010. A list of women psychoanalysts in Great Britain in the twentieth century includes Enid Balint and Clare Winnicott. ${ }^{16}$ Enid Balint (1903-94) was a social worker and psychoanalyst. She married Michael Balint in 1953 and introduced him to casework techniques she used to train social workers. These formed the basis for Balint groups in which transference and countertransference are used to analyse clinical cases and the doctor-patient relationship. Balint methodology is usually attributed to Michael but evidence indicates that Enid needs attribution.

Clare Winnicott (1906-84) also trained as a social worker and psychoanalyst and taught at the London School of Economics (LSE) throughout her career. She was interested in the psychic life of children who had suffered loss and separation, how to communicate with them and the role of social workers as 'transitional participants'. She described ideas such as 'transitional objects' before she married Donald Winnicott in 1951. Whose idea was 'the good-enough mother'?

Attribution for the ideas and work of women therapists, doctors and scientists has been skewed for years, their contributions being invisible and/or claimed by male colleagues. Famous examples include Rosalind Franklin's work on DNA crystallography and June Almeida's discovery in 1964 of coronaviruses.

In addition to statutory and private mental health service developments, since 1960 there has been an expansion in voluntary organisations and self-help information for people in emotional distress and managing mental illnesses (see also Chapter 14). ${ }^{17}$

\section{Women Psychiatrists}

When training as a medical student and psychiatrist in the 1970s and 1980s it was not unusual for a lecturer to announce 'I will refer to the doctor as He and the patient as She, whatever their sex, just for clarity'.

In 1894, after a year debating whether 'man/men' could include woman/women the Medico-Psychological Association (MPA, predecessor of the Royal College of Psychiatrists) rewrote its rules and admitted its first woman psychiatrist Eleanora Fleury (1867-1960). Helen Boyle (1869-1957) became a member of the MPA in 1898 and, in 1939, became its first woman president. ${ }^{18}$

A 1960s analysis of medical staffing predicted that, in 1964, 1,730 medical students would qualify as doctors, 1,330 men and 400 women. They assumed two-thirds 'wastage' of women to marriage, leaving 1,464 'working doctors'. ${ }^{19}$ In 1967, 30 per cent of the UK medical school intake were women. Two surveys of qualified women doctors, by the Medical Practitioners Union and the Medical Women's Federation, found that 80 per cent of respondents actively worked as doctors and nearly half were in full-time work. The researchers concluded that 'the overall wastage of women doctors is not as alarming as is suggested'.

In 1974, the then health secretary Barbara Castle expressed her intention to improve opportunities for women working part-time in the NHS. Part-time and flexible jobs and 
training posts now offered options for different work-life balance choices for women and men professionals working in mental health services.

Psychiatrists Jane Mounty, Anne Cremona and Rosalind Ramsay describe the Women in Psychiatry Special Interest Group (WIPSIG) within the Royal College of Psychiatrists. Its initial objectives were to improve both the working lives of women psychiatrists and the provision of care to women using mental health services. The need for part-time jobs and job-shares had been acknowledged, but employers preferred full-time doctors who, at that time, worked up to eighty hours per week. ${ }^{20}$

They note that 'by November 2003, $47 \%$ of core trainees, $53 \%$ of higher trainees, $55 \%$ of staff grade and associate specialists, and $36 \%$ of consultants in psychiatry, were women. Twenty-two per cent of College Fellows were women, and there were 21 women professors of psychiatry. One in five higher trainees was training flexibly.'

The second aim of this group was to highlight the service provisions for women patients. Professor Dora Kohen is quoted thus:

Half the patients in mental health services are women, although in Old Age services women outnumber men by 2:1 (women live longer). Anxiety, depression and eating disorders are all more common in women. Socio-economic and psychological factors associated with poverty, unemployment and social isolation play a considerable part in female mental illness. Other disorders such as puerperal psychosis, postnatal depression and premenstrual dysphoric disorder are specific to women. ${ }^{21}$

Gender inequality continues in clinical and academic medicine. In a recent review of the evidence for inequalities in pay, career progression, citations and authorships of academic papers, clinical awards and senior leadership roles, the authors conclude that 'equality is not just about having a level playing field, it is about unleashing talent'. They challenge science journals to improve the gender balance of their editorial boards. ${ }^{22}$

\section{Conclusion}

In 1988, Punch magazine published the Miss Triggs cartoon, now guaranteed immortality by its reproduction in Mary Beard's book Women and Power: A Manifesto. ${ }^{23}$ It is a line drawing of an unspecified board meeting of five men and one woman, with the caption 'That's an excellent suggestion, Miss Triggs. Perhaps one of the men here would like to make it.'

Most women immediately recognise this situation. It's a common experience of everyday sexism which includes silencing, misattribution of skills, talents and contributions, and gender inequality.

Add to this social and institutional structures that perpetuate inequality and discrimination and the toll on women's mental health seems obvious. In 2010, social media had not yet become ubiquitous and its effect on young people's mental health, particularly that of young women, was not known. However, it was known that one in four women experienced domestic abuse, only 6 per cent of rape cases resulted in prosecution and that the prevalence of mental illnesses in young women and teenage girls was increasing. Unforeseen events such as economic collapse and new disease outbreaks seem to affect women disproportionately in their 'double shift' responsibilities (career and domestic) and a world that remains, predominantly, designed for men. ${ }^{24}$ 


\section{Wish You Were Here by Sophie McKay Knight (2016)}

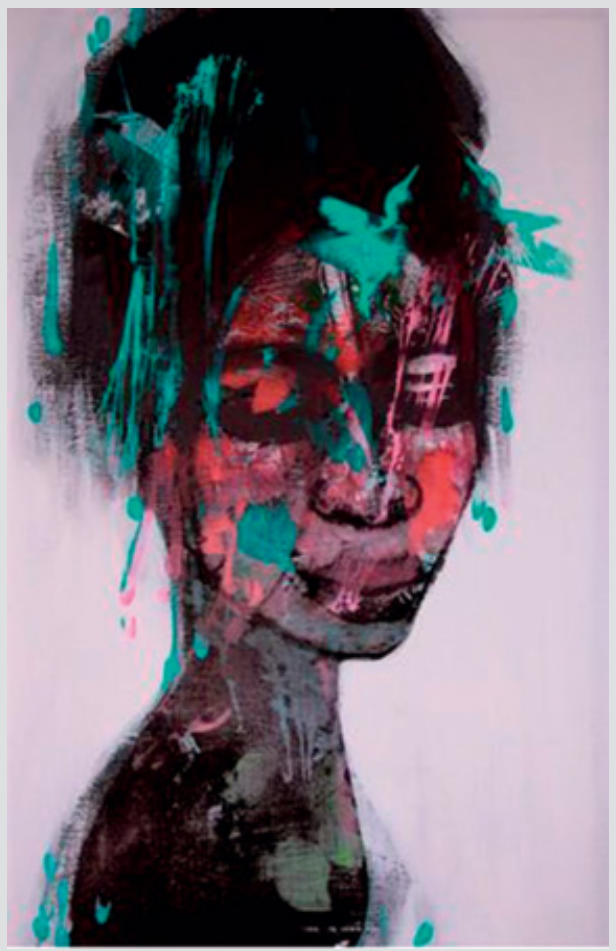

Wish You Were Here is part of the Chrysalis project at the University of St Andrews, in which conversations of women at all stages of their careers in science research were interpreted by the artist Sophie McKay Knight. The images she created were displayed in the Byre Gallery in St Andrews as part of the Women in Science Festival 2016. Sophie McKay Knight has said of this artwork,

Throughout it all I was thinking about what people had told me about being apart from loved ones in order to pursue their careers \& the instability of contracts and not really having any permanence. The single figure in 'Wish you were here' represents that dual positive/negative sense of being alone and yet deeply connected to 'work' which both does and does not make up for any associated loss. ${ }^{25}$

\section{Key Summary Points}

- Women's lives changed profoundly between 1960 and 2010. The main contribution to this was hormonal contraception and its impact on women's mental and physical health.

- Mental health services changed from asylum-based inpatient facilities to communitybased services and from male doctor-dominated organisations towards multidisciplinary collegiate teamwork. 
- By 2010, discrimination and inequality persisted despite forty years of laws making these illegal.

- While many organisations now monitor gender equality data, research is needed to discover why inequality and discrimination are so resistant to change and what factors perpetuate this status quo.

- The effects of social stresses, economic or pandemic, seem to disproportionately burden women who work 'double shifts' to balance work and home commitments with predictably adverse effects on their mental and physical health.

\section{Notes}

1. J. Worth, Call the Midwife. London: Merton Books, 2002.

2. Henry Fawcett. Wikipedia entry, https://en.wikipedia.org/wiki/Henry_Fawcett.

3. J. J. Bradley, Sixty years in psychiatry. Medico-Legal Journal (2017) 85(4): 210-14, https://doi.org/10.1177/ 0025817217721381.

4. C. Hilton, A woman the government feared: Barbara Robb (1912-1976). In G. Rands, ed., Women's Voices in Psychiatry, 205-14. Oxford: Oxford University Press, 2018.

5. B. Friedan, The Feminine Mystique. London: Penguin, 2010. (Originally published in 1963.)

6. G. Ferry, Heather Ashton obituary. The Guardian, 18 November 2019. H. Ashton, Benzodiazepines: How They Work and How to Withdraw [The Ashton Manual], online publication, www.benzo.org.uk/bzmono.htm.

7. NSPCC Learning, Gillick competency and Fraser guidelines, NSPCC Learning website, June 2020, https:// learning.nspcc.org.uk/child-protection-system/gillick-competence-fraser-guidelines; see also Gillick v West Norfolk and Wisbech AHA [1985] UKHL 7 (17 October 1985), House of Lords, www.bailii.org/uk/cases/ UKHL/1985/7.html) (HL).

8. K. Abel and R. Ramsay, The Female Mind: A User's Guide. London: RCPsych Publications, 2017.

9. Bradley, Sixty years in psychiatry.

10. The Equality Act 2010, www.legislation.gov.uk/ukpga/2010/15/pdfs/ukpga_20100015_en.pdf.

11. Friedan, The Feminine Mystique.

12. Patricia Hill Collins. Wikipedia entry, https://en.wikipedia.org.wiki/Patricia_Hill_Collins.

13. HM Government, The Kerr/Haslam Inquiry [report]. Cm. 6640. www.gov.uk/government/publications/thekerrhaslam-inquiry-report.

14. Safeguarding Vulnerable Groups Act 2006. Wikipedia entry, https://en.wikipedia.org.wiki/ Safeguarding_Vulnerable_Groups_Act_2006.

15. P. S. Penfold and G. A. Walker, Women and the Psychiatric Paradox. Montreal: Eden Press, 1983, p. 245.

16. Women psychoanalysts in Great Britain. Psychoanalytikerinnen: Biografisches Lexikon, www.psychoanalyti kerinnen.de/greatbritain_biographies.html.

17. Abel and Ramsay, The Female Mind.

18. F. Subotsky, The entry of women into psychiatry. In Rands, Women's Voices in Psychiatry, 39-49.

19. A. Rimmer, A history of women in British medicine. In Rands, Women's Voices in Psychiatry, 25-38.

20. J. Mounty, A. Cremona and R. Ramsay, History of the Royal College of Psychiatrists' Women's Mental Health Special Interest Group. In Rands, Women's Voices in Psychiatry, 57-72.

21. Ibid., p. 66. 
22. J. F. Breedvelt, S. Rowe, H. Bowden-Jones et al., Unleashing talent in mental health sciences: Gender equality at the top. British Journal of Psychiatry (2018) 213(6): 679-81, https://doi.org/10.1192/bjp.2018.249.

23. M. Beard, Women and Power: A Manifesto. London: Profile Books, 2017.

24. C. Criado Perez, Invisible Women: Exposing Data Bias in a World Designed for Men. London: Chatto \& Windus, 2019.

25. The project artwork is available under the Creative Commons Attribution (CC BY 4.0) terms and conditions: https://creativecommons.org/licenses/by/4.0. Credit: Chrysalis, paintings exploring women in science. Credit: Original painting (acrylic on canvas) by Sophie McKay Knight, with imagery contributed by women scientists from the University of St. Andrews, as part of the Chrysalis Project coordinated by Dr Mhairi Stewart. Attribution 4.0 International (CC BY 4.0). 